\title{
Colorectal Cancer Pathologic Distant Metastasis TNM Finding v6
}

National Cancer Institute

\section{Source}

National Cancer Institute. Colorectal Cancer Pathologic Distant Metastasis TNM Finding v6. NCI Thesaurus. Code C60838.

A pathologic finding about one or more characteristics of colorectal cancer, following the rules of the TNM AJCC v6 classification system as they pertain to distant metastases. 